\title{
Pelatihan Pembuatan Proposal Penelitian PTK bagi Guru-Guru di Kabupaten Way Kanan
}

\author{
Dedy Miswar*, Sugeng Widodo, Zulkarnain, Nani Suwarni \\ Pendidikan Geografi, Universitas Lampung, Bandar Lampung, 35145, Lampung, Indonesia
}

\begin{abstract}
Abstrak.
Tujuan dari pelatihan pembuatan proposal penelitian PTK bagi guru-guru di Kabupaten Way Kanan adalah memotivasi guru untuk meningkatkan kemampuan dalam melakukan PTK, memberikan keterampilan langsung untuk melakukan dan melakukan PTK yang praktis, memberikan pemahaman pada guru akan kebermanfaatan PTK untuk meningkatkan kualitas pembelajaran di sekolah, melatih para guru agar dapat membuat sendiri proposal PTK. Oleh karena itu, dengan melihat realita dan urgensi tersebut, diasumsikan bahwa para guru masih banyak yang belum memahami dan mengerti tentang PTK dan bagaimana membuat proposalnya. Sehingga, untuk menunjang kegiatan pembelajaran di kelas diperlukan suatu kesiapan para guru baik keterampilan melakukan PBM, maupun pengetahuan serta teknik bagaimana membuat proposal penelitian PTK. Sebagai akibatnya, pembelajaran selama ini bersifat teoritis dan monoton dengan permasalahan yang ada di kelas terus berlangsung.
\end{abstract}

Kata kunci.

Proposal, PTK, Way Kanan.

\section{PENDAHULUAN}

Sejak diberlakukannya Undang-undang RI Nomor 14 Tahun 2005 tentang Guru dan Dosen, merupakan bukti pengakuan terhadap profesionalitas pekerjaan guru dan dosen semakin mantap. Terlebih lagi di dalam pasal 14 dan 15 Undang-undang tersebut dinyatakan bahwa guru berhak memperoleh penghasilan di atas kebutuhan hidup minimum dan jaminan kesejahteraan sosial, meliputi gaji pokok, tunjangan yang melekat pada gaji, serta penghasilan lain berupa tunjangan profesi, tunjangan fungsional, tunjangan khusus, dan maslahat tambahan yang terkait dengan tugasnya sebagai guru yang ditetapkan dengan prinsip penghargaan atas dasar prestasi [1].

Bagi para guru pengakuan dan penghargaan di atas harus dijawab dengan meningkatkan profesionalisme dalam bekerja. Guru tidak selayaknya bekerja as usual seperti era sebelumnya, melainkan harus menunjukkan komitmen dan tanggung jawab yang tinggi. Setiap kinerjanya harus dapat dipertanggung jawabkan baik secara publik maupun akademik. Untuk itu ia harus memiliki landasan teoretik atau keilmuan yang mapan dalam melaksanakan tugasnya mengajar maupun membimbing peserta didik [2].

\section{* Corresponding author: dedy.miswar@fkip.unula.ac.id}

Received 18 November 2020; Received in revised form 28 November 2020; Accepted 9 December 2020 Available online 24 December 2020

Lembaga Penelitian dan Pengabdian Kepada Masyarakat

Universitas Lampung 
Dalam kegiatan pembelajaran, seorang guru sudah pasti akan berhadapan dengan berbagai persoalan baik menyangkut peserta didik, subject matter, maupun metode pembelajaran. Sebagai seorang profesional, guru harus mampu membuat prefessional judgement yang didasarkan pada data sekaligus teori yang akurat. Selain itu guru juga harus melakukan peningkatan mutu pembelajaran secara terus menerus agar prestasi belajar peserta didik optimal. Untuk mewujudkan hal tersebut guru harus dibekali dengan kemampuan meneliti, khususnya Penelitian Tindakan Kelas.

Peran pengawas sebagai pembina dan pembimbing guru tentu sangat dibutuhkan, hal ini sesuai dengan Permendiknas no. 12 tahun 2007 tentang Standar Pengawas Sekolah/ Madrasah. Pengawas tidak hanya berperan sebagai resources person atau konsultan, bahkan dapat secara kolaboratif bersama-sama dengan guru melakukan penelitian tindakan kelas bagi peningkatan pembelajaran. Dengan catatan permasalahan yang diangkat adalah persoalan guru dalam proses pembelajarannya

Dewasa ini, dengan adanya sertifikasi guru para pendidik dituntut untuk mampu meneliti. Tuntutan agar guru mampu meneliti semakin gencar dilakukan oleh pemerintah. Hal itu dibuktikan dari laporan portofolio guru yang mensyaratkan melampirkan karya tulisnya dalam sertifikasi guru dalam jabatan karena hal itulah maka guru-guru di sekolah harus dapat meneliti di kelasnya sendiri dengan tujuan memperbaiki kualitas pembelajaran-nya melalui Penelitian Tindakan Kelas (PTK). PTK sesungguhnya merupakan implementasi dari kreativitas dan kekritisan seorang guru terhadap apa yang sehari-hari diamati dan dialaminya sehubungan dengan profesinya untuk menghasilkan kualitas pembelajaran yang lebih baik sehingga mencapai hasil belajar yang optimal.

Namun, sangat disayangkan masih banyak guru-guru yang belum mengenal dan belum melakukan PTK sama sekali di kelasnya. Sehingga tujuan dari worshop ini adalah mengajak atau memotivasi guru yang masih enggan mengadakan penelitian karena berbagai alasan untuk dapat mengembangkan potensi siswa yang ada di kelasnya. Dengan mengetahui potensi siswa, guru menjadi semakin dekat dengan para siswanya, dan terjadilah proses interaktif di antara guru dan siswa.

Workshop ini juga mengajak teman-teman guru untuk melangkah kepada berbagai catatan yang setelah diolah dapat mewujud menjadi suatu penelitian yang berkualitas. Melaksanakan penelitian tentang apa yang sehari-hari dilakukan oleh seorang guru yang akhirnya dapat menghasilkan suatu karya yang disebut PTK. Hal itu dapat terjadi apabila suatu urutan umum prosedur, yaitu bermula dari identifikasi masalah penelitian yang dihadapi sampai dengan laporan hasil akhirnya dicatat. Jadi, amat penting suatu prosedur ini dipahami dan ditaati oleh guru yang meneliti.

Penelitian di bidang pendidikan memang memerlukan sejumlah instrumen (toolbox) yang terdiri dari berbagai pendekatan untuk mengkaji berbagai isu pendidikan dalam masyarakat kita. Tidak cukup pendidikan formal membatasi diri pada eksperimen atau penelitian yang hanya berkenaan dengan kurikulum ataupun masalah-masalah yang terungkap dalam buku pelajaran. Seharusnya praktek pendidikan lebih menerobos kepada kehidupan nyata, mengajak peserta didik untuk tidak saja berpikir pada kala ia belajar, tetapi lebih banyak belajar untuk berpikir lebih dalam tentang berbagai masalah dalam kehidupan ataupun lingkungan sekitar [3].

Melalui berbagai cara yang telah dipaparkan, berbagai masalah itu akan membuka pikiran kita dalam menemukan berbagai solusi untuk mengatasi berbagai kesenjangan masalah pembelajaran. Dengan memahami dan memperhatikan karakteristik setiap siswa, maka guru akan dapat mengembangkan potensi unik yang dimiliki oleh setiap siswa dengan melakukan berbagai tindakan yang terhimpun ke dalam sebuah penelitian tindakan kelas (PTK). Melalui PTK yang dirancang guru, para guru diharapkan dapat menemukan potensi unik siswa yang berujung kepada peningkatan hasil belajar.

Oleh karena itu, dengan melihat kepada realita dan urgensi tersebut, diharapkan para guru dapat aktif menulis, meneliti dan menuliskan laporan penelitiannya sehingga dapat meningkat-kan kualitas pembelajarannya di kelas. 


\section{METODE}

Kegiatan Sosialisasi Pembuatan Karya Ilmiah ini merupakan wadah bagi guru untuk melakukan serangkaian upaya yaitu kegiatan refleksi, penemuan masalah, pemecahan masalah melalui beragam strategi untuk meningkatkan keterampilan dalam mengelola pola pikir ilmiah khususnya Penelitian Tindakan Kelas. Oleh karena itu pengabdian masyarakat yang di kemas dalam kegiatan pelatihan kepada para guru perlu dilakukan. untuk lebih jelasnya keadaan awal dan keadaan akhir yang diharapkan dari perilaku guru-guru peserta dapat dilihat pada Tabel 1.

Tabel 1. Keadaan awal dan keadaan akhir yang diharapkan dari guru peserta pelatihan pembuatan PTK pada guru-guru tahun 2020 .

\begin{tabular}{llll}
\hline No & \multicolumn{1}{c}{ Keadaan Awal } & \multicolumn{1}{c}{ Perlakuan } & \multicolumn{1}{c}{ Keadaan Akhir } \\
\hline 1 & $\begin{array}{l}\text { Guru peserta kurang } \\
\text { menguasai pengetahuan } \\
\text { tentang PTK }\end{array}$ & $\begin{array}{l}\text { Pemberian materi tentang } \\
\text { teori-teori, konsep, PTK }\end{array}$ & $\begin{array}{l}\text { Guru peserta dapat mengetahui, } \\
\text { memahami dan menguasai teori, } \\
\text { konsep, prinsip pembuatan PTK }\end{array}$ \\
2 & $\begin{array}{l}\text { Guru peserta belum dapat } \\
\text { membuat proposal PTK }\end{array}$ & $\begin{array}{l}\text { Latihan membuat proposal } \\
\text { PTK }\end{array}$ & $\begin{array}{l}\text { Guru peserta dapat membuat } \\
\text { proposal PTK }\end{array}$ \\
\hline
\end{tabular}

Berdasarkan tabel di atas dapat dilihat bahwa kemampuan guru dalam membuat proposal PTK masih rendah.

Sasaran kegiatan pengabdian ini adalah seluruh guru peserta pelatihan pembuatan proposal penelitian PTK pada umumnya. Rencana tempat kegiatan dipusatkan di Kabupaten Way Kanan tahun 2020. Kegiatan ini diikuti oleh 15 guru. Kegiatan ini dilaksanakan selama 3 hari, dimulai tanggal 18,19, dan 21 Agustus 2020.

\section{Metode Ceramah}

Metode ceramah, yaitu dengan memberikan penjelasan dengan berbicara, agar para guru memperoleh pengetahuan atau wawasan tentang konsep PTK yang digunakan dalam proses belajar mengajar di sekolah dalam rangka peningkatan kualitas pembelajaran di sekolah.

Metode ini digunakan untuk menyampaikan materi pelatihan yang bersifat kognitif seperti teori, konsep, prinsip serta langkah dalam menyusun, dan membuat PTK. Dalam pelakasanaan metode ini digunakan waktu sebanyak 40\% untuk ceramah atau penyampaian materi, sedangkan sisanya $60 \%$ digunakan untuk diskusi dan tanya jawab.

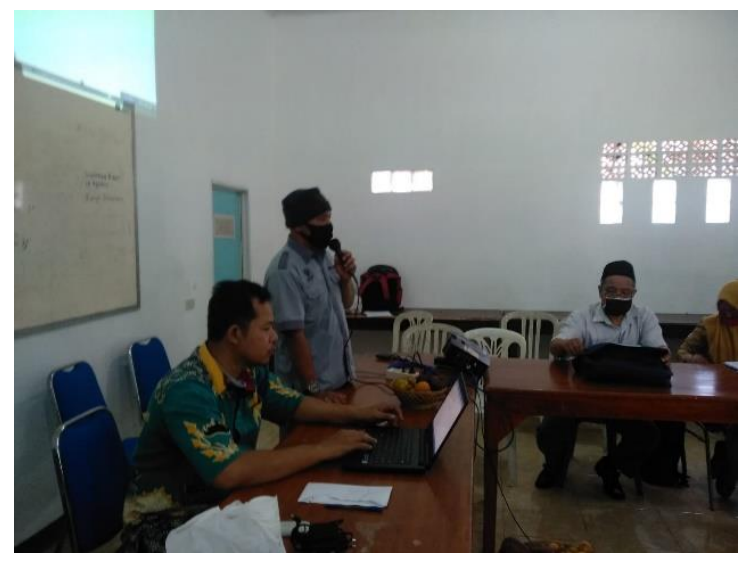

Gambar 1. Penyampaian Materi Tim.

\section{Metode Pembimbingan dan Pelatihan}

Dalam metode ini, kegiatan utama yang dilaksanakan adalah pembimbingan dan pelatihan bagi peserta untuk menerapkan atau mengaplikasikan materi-materi yang telah disampaikan sebelumnya. Dalam pelaksanaan metode ini digunakan waktu sebanyak $70 \%$ untuk pembimbingan dan pelatihan, sedangkan 30\% digunakan unntuk diskusi dan tanya jawab. 


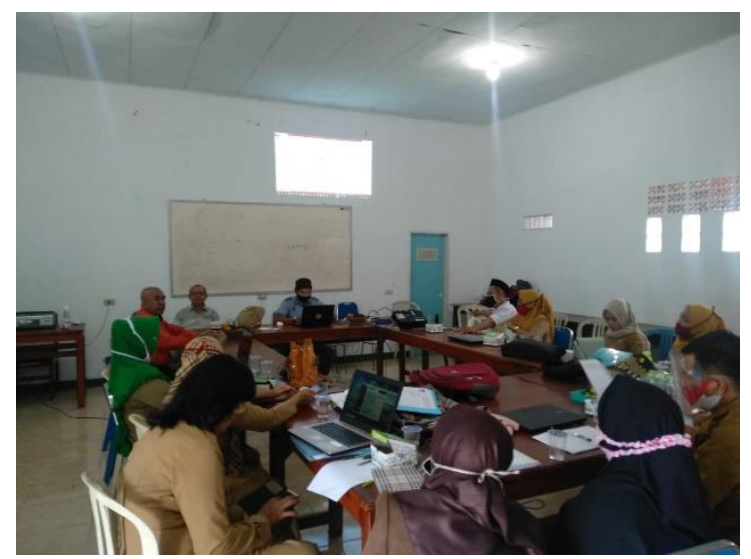

Gambar 2. Pendampingan pembuatan Proposal PTK.

Pelaksanaan pelatihan dengan cara tatap muka dilakukan selama satu hari yaitu tanggal 18, sedangkan untuk 2 hari berikutnya dilakukan dengan bimtek secara daring, hal ini karena kondisi yang tidak memungkinkan untuk melaksanakan tatp muka, mengingat kondisi covid-19.

\section{HASIL DAN PEMBAHASAN}

Kegiatan pengabdian dosen berjudul "Pelatihan Pembuatan Proposal Penelitian Tindakan Kelas (PTK) Bagi Guru-Guru di Kabupaten Way Kanan", dilakukan dengan acara tatap muka dan bimbingan Teknis juga daring yang diselenggarakan di Kabupaten Way Kanan pada hari rabu, tanggal 18, 19, dan 21 Agustus 2020. Pertemuan ini dihadiri oleh 15 orang guru (daftar hadir peserta terlampir). Agenda kegiatan pengabdian dilakukan pemaparan materi dengan nara sumber adalah tim pengabdi yang berjumlah 4 (empat) orang. Penyampaian materi dari tim pengabdi, antara lain: materi PTK, Siklus PTK, Format proposal PTK, dan Analisis PTK. Penyampaian materi kemudian dilanjutkan dengan sesi tanya jawab mengenai berbagai kendala yang dihadapi guru dalam PTK termasuk dalam pembuatan proposal. Kegiatan pengabdian kemudian diikuti dengan praktik berupa pembuatan proposal PTK oleh peserta, latar belakang masalah, rumusan masalah, tujuan, dan bentuk tindakan yang akan dilakukan, dan seterusnya sampai pada proposal yang sudah siap. Kegiatan pengabdian dilanjutkan dengan pemberian tugas individu pada para guru untuk membuat proposal PTK. Tugas individu bagi guru dikumpulkan secara kolektif melalui Kepala Sekolah dan diberikan kepada tim pengabdi untuk mendapatkan masukan dalam rangka perbaikan. Pendampingan dilakukan oleh tim pengabdi dengan harapan semakin banyak guru-guru SMA di Kabupaten Way Kanan yang mengimplementasikan PTK dan sekaligus menulis laporannya.

Hasil Pelaksanaan Kegiatan Pengabdian Kepada Masyarakat secara keseluruhan dapat dilihat berdasarkan beberapa komponen berikut ini:

1. Ketercapaian target jumlah peserta pelatihan atau khalayak sasaran adalah 15 orang guru yang terdapat pada sekolah tersebut. Dalam pelaksanaannya kegiatan ini diikuti oleh 15 orang guru karena ada beberapa guru yang mempunyai kegiatan di sekolah masing-masing. Dengan demikian ketercapaian target jumlah peserta pelatihan adalah $75 \%$ atau dapat dinilai baik.

2. Ketercapaian tujuan pelatihan dapat dinilai kurang baik. Dalam kurun waktu 2 (dua) minggu sebanyak 11 orang guru (75\%) telah berusaha membuat proposal PTK. Kendala yang dihadapi para guru dalam pengerjaan tugas individu adalah kesibukan di sekolah dan masih minimnya kemampuan menulis, oleh karena itu perlu adanya pengalakan budaya menulis. Dalam kegiatan pengabdian ini, tim pengabdi berusaha melakukan pendampingan bagi bapak/ibu guru yang tertarik mengimplementasikan PTK dan berlatih menulis laporannya.

3. Ketercapaian target materi yang telah direncanakan direncanakan pada kegiatan 
pengabdian ini dapat dinilai baik (80\%). Semua materi yang telah direncanakan dapat disampaikan kepada peserta, meskipun karena keterbatasan waktu ada beberapa materi yang hanya disampaikan secara garis besar.

4. Kemampuan peserta dalam penguasaan materi Kemampuan peserta dilihat dari penguasaan materi dapat dinilai baik (80\%). Hal ini dapat dilihat dari kemampuan bapak/ibu guru dalam kegiatan praktik berupa pembuatan PTK, latar belakang masalah, rumusan masalah, tujuan, dan bentuk tindakan yang akan dilakukan, disamping antusiasme dalam acara tatap muka dengan memberikan beberapa pertanyaan. Secara keseluruhan, kegiatan pengabdian bagi guru-guru diukur dari keempat komponen di atas dapat dinilai baik. Hal ini berkat dukungan banyak pihak, terutama MGMP, Kepala Sekolah, dan LP2M Universitas Lampung, serta steakholder terkait lainnya.

Afandi [4] mengatakan bahwa teori dan Praktik Penelitian Tindakan Kelas Secara teoritis PTK memang seharusnya dapat dirasakan sebagai kebutuhan oleh para pendidik pada semua jenjang pendidikan. Akan tetapi dalam merancang dan melaksanakan PTK, masih cukup banyak pendidik yang merasa terbebani jika dituntut untuk melaksanakan PTK. Akibatnya, masih banyak guru yang tidak bahkan tidak mampu melaksanakan dan menulis hasil PTK. Alasan-alasan yang menyebabkan kurang aktifnya guru melaksanakan kegiatan PTK antara lain ialah: Pertama, guru berpikir bahwa PTK adalah suatu proses dan produk dari kelompok di luar guru (outsider researcher).

Peneliti yang berasal dari luar guru, merasa berperan sebagai ahli dalam menghasilkan teori dan juga cenderung mengasumsikan bahwa pengetahuan tentang pembelajaran harus dikeluarkan berupa teori dari hasil pikiran peneliti. Oleh karena itu, peneliti selain guru seringkali kurang memperhatikan guru pada saat mengembangkan suatu teori., Kedua, pandangan negatif terhadap teori PTK menjadi meningkat jika teori tersebut disampaikan dalam bentuk generalisasi bagi praktik pembelajaran oleh guru secara keseluruhan. Semakin umum teori yang dikembangkan oleh peneliti, maka guru dan pihak sekolah akan semakin merasa terganggu sebab menurut pandangan guru, teori dapat berten-tangan dengan kenyataan yang terjadi atau dialami di sekolah. Ketiga, model yang dikembangkan oleh para ahli (peneliti luar) mungkin berasal dari kondisi masyarakat yang ideal. apabila guru menerapkannya di kelas dalam bentuk PTK, mungkin akan menimbulkan efek yang tidak diinginkan.

Efek samping tersebut dapat: 1) menghasilkan ketidakseimbangan sosial dan ketidakadilan dalam masyarakat, 2) mening-katkan pola berpikir pasif dan menghambat berpikir kritis, 3) menggambarkan kedang-kalan dan keterbatasan konsepsi mengenai potensi kemampuan manusia sehingga mengurangi rasa percaya diri dan menghambat perkembangan individual, 4) memutuskan perolehan pengetahuan dari pengembangan kapasitas untuk menilai dan diskriminasi dalam kompleksitas kehidupan sehari-hari.

Generalisasi sebenarnya tidak secara langsung membebani atau mengancam posisi guru sebab generalisasi menunjukkan keteraturan di mana guru secara individual tidak mampu mengontrolnya. Hal lain yang membebani guru adalah bahwa generalisasi mengimplikasikan evaluasi negatif guru seperti kegagalan untuk melaksanakan model ideal pembelajaran. Secara teoritis, generalisasi memposisikan guru pada apa yang disebut oleh Ronald Lang sebagai situasi ikatan ganda (double band) di mana guru dianggap bersalah meskipun sebenarnya guru telah melaksanakan tugasnya dalam keadaan menghindari kesalahan. Singkatnya dalam upaya melakukan perubahan melalui pelaksanaan PTK guru berhadapan dengan berbagai masalah baik yang bersifat eksternal maupun internal.

Masalah-masalah eksternal dapat berupa: 1) kurang jelasnya hubungan antara model pembelajaran teoritis dan penerapannya di kelas, 2) padatnya kurikulum dan silabus yang harus dilakukan guru dalam menjalankan tugas kesehariannya, 3) adanya tuntutan terhadap guru untuk mengejar target silabus dan mempersiapkan siswa agar berhasil melewati ujian yang umumnya berbasis kognitif.

Sedangkan masalah yang bersifat internal dapat berupa keengganan guru untuk melakukan perubahan karena kurangnya motivasi guru dan kurangnya akses guru terhadap 
sumber-sumber informasi berupa perpustakaan yang menyediakan literatur seperti jurnal, buku, majalah dan internet. Dalam uraian di atas terlihat adanya kesenjangan antara teori dan praktik penelitian tindakan kelas bagi guru. Di satu sisi guru dituntut untuk mengadakan perubahan melalui kemampuan merancang dan melaksanakan penelitian tindakan kelas, sementara di sisi lain guru menghadapi tuntutan birokrasi dan praktik politis misalnya pencapaian target kurikulum dan target kelulusan. Kedua hal itu, menempatkan guru pada posisi yang dilematis. Kondisi seperti inilah yang menyebabkan guru merasa terbebani oleh adanya teori yang merekomendasikan guru untuk melakukan penelitian tindakan kelas.

Secara umum memang ada kesenjangan antara teori dan praktik mengenai penelitian tindakan kelas. Tidak sedikit jumlah guru pada jenjang pendidikan dan menengah bahkan dosen yang merasa terbebani dengan adanya tuntutan agar mau dan mampu melaksanakan penelitian tindakan kelas. Di sisi lain, guru harus memikul beban tugas dan tanggung jawab administratif yang beragam. Akibatnya guru semakin merasa tidak memiliki kemampuan dan kesempatan yang memadai untuk melakukan PTK. Oleh karena itu, diperlukan upaya untuk memotivasi guru agar tertarik untuk melakukan penelitian atas inisiatif sendiri. Pelibatan guru sebagai peneliti pendamping (co-researcher) bagi dosen dalam pelaksanaan PTK tentu akan sangat membantu guru. Selain itu perlu diciptakan peluang dan akses bagi guru untuk mengikuti diseminasi literatur terkait penelitian, serta pemberian dukungan bagi guru terutama pada fase-fase kritis yang dihadapinya berkaitan dengan penelitian tindakan kelas [5].

Guru sebagai jajaran staf pengajar di suatu sekolah secara praktis mengetahui berbagai permasalahan yang dihadapi di kelasnya berkaitan dengan permasalahan pengajaran. PTK itu bersifat practice driven dan action driven. Hal itu bearati bahwa PTK bertujuan memperbaiki pengajaran secara praktis dan secara langsung. Oleh karena itu, banyak kalangan menamakan PTK sebagai penelitian praktis (practical inquiry). PTK hanya memusatkan perhatian pada permasalahan yang spesifik. PTK dapat berjalan dengan baik apabila dalam perencanaan dan pelaksanaannya menggunakan 6 prinsip sebagai berikut:

1. Tugas pertama dan utama guru di sekolah adalah mengajar siswa sehingga apapun metode PTK yang akan diterapkan tidak akan mengganggu komitmen sebagai pengajar.

2. Metode pengumpulan data yang di gunakan tidak menuntut waktu yang berlebihan dari guru sehingga berpeluang mengganngu proses pembelajaran.

3. Prinsif yang ketiga,bahwa metodologi yang digunakan harus cukup reabele sehingga memungkinkan guru mengidentifikasi serta merumuskan hipotesis secara cukup meyakinkan, mengembangkan strategi yang dapat diterapkan pada situasi kelasnya dan memperoleh data yang dapat digunakan untuk "Menjawab"hipotesis yang di kemukakannya.

4. Masalah penelitian yang diusahakan oleh guru seharusnya merupakan masalah yang merisaukannya. Bertolak dari tanggung jawab profesionalnya,guru sendiri memiliki komitmen ini juga diperlukan sebagai motivator intrinsik bagi guru untuk"bertahan"dalam pelaksanaan kegiatan yang jelas-jelas menuntut lebih dari yang sebelumnya diperlukan dalam rangka pelaksanaan tugas-tugas pengajarnya.

5. Dalam menyelenggarakan PTK, Guru harus selalu bersikap konsisten menaruh kepedulian tinggi terhadap prosedur etika yang berkaitan dengan pekerjaannya. Hal ini penting ditekankan karena selain melibatkan anak-anak manusia,PTK juga hadir dalam suatu konteks organisasional sehingga penyelenggaraannya harus mengindahkan tatakrama kehidupan berorganisasi.

6. Kelas merupakan cakupan tanggung jawab seorang guru, namun dalam pelaksanaan PTK sejauh mungkin digunakan classroom excedding perspektive, dalam arti permasalahan tidak dilihat terbatas dalam konteks dalam kelas atau mata pelajaran tertentu, melainkan dalam perspektif yang lebih luas ini akan berlebih-lebih lagi terasa urgensinya apabila dalam suatu PTK terlibat dari seorang pelaku. 


\section{KESIMPULAN DAN SARAN}

\section{Kesimpulan}

Berdasarkan pada hasil dan pembahasan sebelumnya tentang kegiatan pelatihan pembuatan proposal PTK, ada beberapa yang dapat disimpulkan, antara lain:

1. Kegiatan pengabdian yang dilakukan oleh Tim Pengabdian Universitas Lampung dengan metode ceramah dan bimtek secara daring telah mampu meningkatkan motivasi, keterampilan dan pemahaman guru-guru atau peserta tentang PTK dan diharapkan guru dapat sekaligus membuat proposalnya.

2. Pembuatan proposal PTK diharapkan sebagai salah satu upaya pengembangan profesi dan sekaligus membantu guru dalam pencapaian angka kredit yang diperlukan untuk kenaikan pangkat.

\section{Saran}

Saran yang dapat diberikan dalam pelatihan pembuatan proposal ini adalah:

1. Agar pelaksanaan kegiatan pengabdian tentang PTK dapat mencapai sasaran yang diharapkan, maka perlu adanya observasi lapangan mengenai kebutuhan guru-guru di wilayah yang menjadi lokasi pengabdian.

2. Kegiatan pengabdian yang sejenis diharapkan dapat dilakukan pada tahuntahun berikutnya di lokasi lain untuk menjembatani antara pihak perguruan tinggi dan sekolah untuk ikut serta meningkatkan kualitas pendidikan di Indonesia.

\section{UCAPAN TERIMA KASIH}

Terima kasih disampaikan kepada LPPM Universitas Lampung yang telah mendanai kegiatan Pengabdian Masyarakat ini.

\section{DAFTAR PUSTAKA}

[1] Aqib, Z., \& Chotibuddin, M. 2018. Teori dan Aplikasi Penelitian Tindakan Kelas: (PTK). Deepublish.

[2] Jayanta, I. N. L., Rati, N. W., Diputra, K. S., \& Wibawa, I. M. C. 2017. Pelatihan penyusunan proposal penelitian tindakan kelas bagi guru-guru sd. Widya Laksana, 6(1), 1-7.

[3] Hanafi, M. 2015. Community Based Research Panduan Merancang dan Melaksanakan Penelitian Bersama Komunitas.

[4] Afandi, M. 2018. Teori dan Praktik Penelitian Tindakan Kelas.

[5] Jufri, A. W. 2010. Penelitian Tindakan Kelas: Antara Teori Dan Praktek. Jurnal Pijar Mipa. 5(2). 